\title{
Development and quality evaluation of unriped mango and Aloe-vera RTS (ready to serve) beverage
}

\author{
D. S. Mondhe ${ }^{1 *}$, G. D. Patil ${ }^{1}$, S.D. Jadhav², V. G. Mohite ${ }^{2}$ and D. L. Gavit ${ }^{2}$ \\ ${ }^{1}$ Department of Agricultural Process Engineering, K.K. Wagh College of Agriculture Engineering and Technology, Nashik (M.S.) \\ India \\ ${ }^{2}$ Department of Agricultural Engineering, K.K. Wagh College of Agriculture Engineering and Technology, Nashik (M.S.) India \\ Email : dsmondhe@kkwagh.edu.in
}

\begin{abstract}
SUMMARY :
The present research work was undertaken to develop the technology for development and quality evaluation of unriped mango and Aloe vera RTS beverage prepared from unriped mango juice and Aloe vera juice and to study the changes in chemical composition and sensory qualities of the RTS with different proportions of juice of unriped mango and Aloe vera held at the department of Agricultural Process Engineering, K.K Wagh College of Agriculture Engineering and Technology. Different treatments were used for the study using different proportion of juice of unriped mango and Aloe vera namely $\mathrm{T}_{1}, \mathrm{~T}_{2}$ and $\mathrm{T}_{3}$. On the basis of sensory score and physio-chemical composition we found that treatment $\mathrm{T}_{3}(60: 40)$ was found best.
\end{abstract}

KEY WORDS : RTS, Chemical analysis, Sensory evalution

How to cite this paper : Mondhe, D.S., Patil, G.D., Jadhav, S.D., Mohite, V.G. and Gavit, D.L. (2018). Development and quality evaluation of unriped mango and Aloe-vera RTS (ready to serve) beverage. Internat. J. Proc. \& Post Harvest Technol., 9 (1) : 34-38. DOI: 10.15740/HAS/IJPPHT/9.1/34-38. Copyright@ 2018: Hind Agri-Horticultural Society. 